\title{
Reflection of William Ernest Henley's Own Life through the Poem Invictus
}

\author{
S.M. Faisal Arafat
}

BCS (General Education), Lecturer in English, Government Viku Memorial College, Manikganj, Bangladesh naadviarafat@gmail.com

\begin{abstract}
The poem 'Invictus' is undoubtedly considered as the finest creation of William Ernest Henley. A Latin word invictus stands for unconquerable in English. The very name of the poem is suggestive of the tone and theme of the poem. It tells about the hardships and struggles of the poet he faced in his own life and at the same time shows the indomitable spirit the poet used to have to fight life and emerge as victorious. This article would endeavour to go deep inside the life of the poet and discover the intimate relation of the poet with his own creation naming the poem 'Invictus'. This paper would also explore a structural analysis of the poem to establish an identification of the larger than life attitude inherent and expressed in the poem itself. It would also be an exploration of Henley's belonging to the famously called Victorian Spirit.
\end{abstract}

Keywords-Invictus, hardships and struggles, life of the poet, structural analysis, Victorian Spirit.

\section{INTRODUCTION}

Edward Albert in his book History of English Literature mentions the sixty years (1830-1890) as commonly included under the name of the Victorian age (367). Henley was born in Gloucester on August 23, 1849. Born after a decade and a half from the start of the Victorian Era in English literature, Henley emerged as an influential poet, critic and editor. Dr Andrzej Diniejko in his scholarly article William Ernest Henley: A Biographical Sketch writes: "William Ernest Henley (1849-1903), an influential editor, critic and poet, had a role in the late-Victorian period similar to that of $\mathrm{Dr}$ Samuel Johnson in the late eighteenth century." He further writes in the same article: "Henley published several books of poetry, but he is best remembered for the poem Invictus (1875), which reflects his resilient struggle with the deadly disease." His biographer Jerome Hamilton Buckley wrote: "By virtue of a single poem William Ernest Henley remains at once the most freely quoted and the most thoroughly neglected of Victorian lyrists." So a commentary in this regard would not be any exaggeration that Henley consciously transformed his personal loss due to his unavoidable consequence of illness into an indomitable spirit and energy through the poem Invictus.

\section{HENLEY'S ILLNESS SND HIS SUBSEQUENT COMPOSITION OF THE POEM}

At the age of 12, Henley was diagnosed with tuberculosis of the bone. The treatment was needed with an amputation below his left knee in 1868-69 (Connell 35). The blow of misfortune continued in his life as his other leg was also infected with tuberculosis. Devastated, but a fighter Henley sought treatment from the pioneering late 19th-century surgeon Joseph Lister at the Royal Infirmary of Edinburgh, commencing in August 1873. Edward Cohen in his article The Second Series of W.E. Henley's Hospital Poems writes:

Henley was admitted to the Royal Infirmary of Edinburgh as Joseph Lister's patient on 22 August 1873. Six dayslater in a procedure conducted under his new antiseptic system of surgery Lister gouged and scraped the necrotic bone from Henley's right foot. The operation was repeated on 12 December, and for the next sixteen months Henley was confined to his bed and constrained by a cast Iron splint. From the beginning he took great interest in the affairs of the wards. He gossiped with his fellow patients. He flirted with the nurses. He observed the clerks, dressers and physicians. On a little desk affixed to his bed he began to transform his hospital episode into poetry. (129)

In spite of his all his illnesses and misfortunes, Henley remained a strong and sociable man with boundless energy, excellent memory, enthusiasm and versatile mind. Leaving 
behind every powerful blow of fate, he was always victorious with the strength of his psyche. He remained invincibility (invictus) personified. "While he stayed in the Edinburgh Infirmary, he read a lot, taught himself French, Spanish, and German, and corresponded with men of letters." (Connell 16). Here in these hospital days Henley wrote his most famous poem and it was published in 1888 in his first volume of poems, Book of Verses, in the section Life and Death (Echoes). Henley, when he wrote the poem, he didn't give any title to the poem as it appeared in his Book of Verses. Sir Arthur Thomas Quiller-Couch, a Cornish writer who as an editor of The Oxford Book of English Verse sought it appropriate to add the present title invictus.

\section{STRUCTURAL ANALYSIS OF THE POEM WITH A VIEW TO DETERMIING HENLEY'S PERSONAL RESEMBLANCES}

The ever unbowed Henley to be reflective of his towering strength of mind and his relentless perseverance writes as the invictus in his most famous poem:

Out of the night that covers me, Black as the pit from pole to pole, I thank whatever gods may be For my unconquerable soul.

In the fell clutch of circumstance I have not winced nor cried aloud. Under the bludgeonings of chance My head is bloody, but unbowed.

Beyond this place of wrath and tears

Looms but the Horror of the shade,

And yet the menace of the years

Finds and shall find me unafraid.

It matters not how strait the gate,

How charged with punishments the scroll,

I am the master of my fate,

I am the captain of my soul.

With a set rhyme scheme of abab cdcd efef ghgh, the poem appears a very simple one containing sixteen lines divided into four stanzas and each stanza comprising of four lines. The poem also has a set rhythm, each line containing eight syllables. But this outward simplicity of the structure of the poem pleasantly uncovers its bulky disguise. And I consciously use the word pleasantly because I believe it would never require any toiling performance even from a very naïve reader to understand the inspirational significance of the poem specially the last two lines directly indicating the indomitable spirit of a person and emerging as popular quotes for the readers. Henley seems to have a plan from the very beginning of the poem as he uses strongest of images at the very outset of the poem. He says, "Out of the night that covers me, / Black as the Pit from pole to pole." The word 'night' as an imagery stands for utter darkness. And as an exaggeration to the effect of the night the word 'black' has been used. These might very well indicate Henley's hospital days as the poet might have discovered his sickbed setting the macrocosm of the entire world into microcosm (pole to pole). The readers can imagine the poet lying on the operation table waiting to be drugged unconscious before being brought under the knife of the doctor. But the spirit of the poet is quite evident as he declares himself as an unconquerable soul in the last line of the first stanza.

It has been mentioned earlier that Henley became a victim of tuberculosis at the age of 12 . The second stanza of the poem is directly reflective of his personal misfortunes. Henley personifies the word 'circumstance' saying he was being clutched by it. The second line of the second stanza can even determine the strength of a twelve year old boy who even suffering from terrible pain due to the disease never shed a drop of tear. The word 'wince' is suggestive of the reaction of extreme pain. The words 'bludgeonings' and 'bloody' are also the images of extremity of pains and sufferings. But even after all these sufferings Henley maintaining the tradition of the first stanza emerges as victorious (unbowed) in the last line of the second stanza.

In the third stanza Henley emerges as a transcendental. It can be a matter of debate that if is accepting religion or denying the existence of it but he is certainly challenging it as he declares: "Beyond this place of wrath and tears / Looms but the Horror of the shade." Henley, quite clearly found earth, to be more specific the hospital as a place of wrath and tears but his words are distinct and clear as he remains unafraid and declares he would be victorious even his illness brings death to him. The word 'shade' here in the second line refers to death.

The challenge to the life after, continues in the fourth and final stanza of the poem. Henley says: "It matters not how strait the gate / How charged with punishments the scroll". The imagery of 'gate' can refer to the gate of heaven or hell. 'Scroll' is the imagery of the poet's chronicles of living in the present world. The poet declares himself on the control of things in his life. The last two lines are the most 
famous in the entire poem. His fearlessness, determination, self belief, and above all his invincibility to stand erect facing a dreadful series of misfortunes transport himself to a certain standard of immortality. Henley, truly and deservingly emerges as 'the invictus':

"I am the master of my fate,

I am the captain of my soul."

\section{THE POEM AS A SOURCE OF INSPIRATION TO OTHERS}

Henley's words in the poem Invictus has been favourite quotes to many famous persons of the world. The last two lines of the poem have been mostly used by people. If a comparison is set in terms of simplicity of words but depth of meaning, then the lines can be a perfect comparison to the last lines of Robert Frost's famous poem Stopping by the Woods on a Snowy Evening as it says:

"And miles to go before I sleep

And miles to go before I sleep"

The most popular representation of the poem is a 2009 American-South African biographical sports drama film by the same name Invictus directed by Clint Eastwood and starring Morgan Freeman and Matt Damon. The story is based on the John Carlin book Playing the Enemy: Nelson Mandela and the Game That Made a Nation about the events in South Africa before and during the 1995 Rugby World Cup. Freeman and Damon respectively played the role of South African President Nelson Mandela and François Pienaar the captain of the South Africa rugby union team, popularly known as The Springboks. The movie was released in the United States on December 11, 2009. Morgan Freeman in the movie impersonating Nelson Mandela calls the poem Invictus as his source of inspiration during his hard fought years of imprisonment in the Robben Island. Morgan freeman later in many of his interviews recited the poem.

\section{CONCLUSION}

What else would be the greatest success of a writer than that a creation of his own outsplenders his own name! Invictus did the same for William Ernest Henley. Henley the writer, Henley the influential editor of Victorian Age, Henley the critic and Henley the poet; all these identities seem to be destined to end up as a milestone as Henley the invictus, Henley the creator of the poem Invictus. Henley died on 11 July 1903, at the age of 53. But he died only because he was a mortal. He died, only because he had to die being a mortal. The man who fought like a legend to create his own legend finally succumbed to his old enemy called tuberculosis. Dr Andrzej Diniejko writes:

In 1902, Henley fell from a railway carriage. This accident caused the latent tuberculosis germ to awaken in his organism. He died on 11 July 1903, at the age of 53 and was buried next to his daughter's grave in the churchyard in Cockayne Hatley, a small village in Bedfordshire.

\section{REFERENCES}

[1] Albert, Edward. History of English Literature. $5^{\text {th }}$ ed., Oxford University Press, 1979, p. 367.

[2] Buckley, Jerome Hamilton. William Ernest Henley: A Study in the Counter-Decadence of the Nineties. Princeton: Princeton University Press, 1945.

[3] Cohen, Edward. "The Second Series of W. E. Henley's Hospital Poems". Yale University Library Gazette, vol. 78, no. $3 / 4, \quad$ April 2004, pp.128-150, https://www.jstor.org/stable/40859569

[4] Carlin, John. Playing the Enemy: Nelson Mandela and the Game That Made a Nation. Penguin Press, 2008.

[5] Connell, John. W.E. Henley. London: Constable, 1949, p. 16, p.35.

[6] Diniejko, Dr Andrzej. "William Ernest Henley": A Biographical Sketch". The VictorianWeb, http://www.victorianweb.org/authors/henley/introduction.html

[7] Frost, Robert. New Hampshire. $1^{\text {st }}$ ed., New York: Henry Holt, 1923.

[8] Henley, William Ernest. A Book of Verses. London: David Nutt, pp. 56-57.

[9] Quiller Couch, Arthur Thomas The Oxford Book of English Verse, 1250-1900. $1^{\text {st }}$ ed., Oxford: Clarendon Press, 1902, p. 1019.

[10] Invictus. Directed by Clint Eastwood, performances by Morgan Freeman, Matt Damon. Liberty Pictures and Warner Bross Productions, 2009.

[11] "Morgan Freeman recites 'Invictus' from memory on Charlie Rose". YouTube, uploaded by Best of Humans, 6 December 2013, https://www.youtube.com/watch?v=a7qvACVwq0

[12] "Nelson Mandela's Favorite Poem 'Invictus' Read by Morgan Freeman". YouTube, uploaded by Somali, 5 December 2015, https://www.youtube.com/watch?v=SAa6qdBN7Z0 